\title{
Hospice Care of a Child Leukemia Acute Lymphoid: Case Report
}

\author{
Diego Silveira Siqueira1*, Aline Silveira Siqueira ${ }^{2}$, Alberto Mauricio Barbosa Moura ${ }^{3}$ and Geovana Fraga \\ Demingos $^{4}$
}

${ }^{1}$ Nurse Care of the Pediatric Intensive Care Unit, Cardiology Institute in Porto Alegre-RS, Brazil

${ }^{2}$ Academic Faculty of Psychology, St. Francis of Assisi, Brazil

${ }^{3}$ Post-Graduate in Psychology, Neuropiscopedagogia Clinic (CENSUPEG), Brazil

${ }^{4}$ Department of Nursing, University Center Ritter dos Reis, Brazil

Submission: November 11, 2018; Published: November 30, 2018

*Corresponding author: Diego Silveira Siqueira, Nurse, PhD student in Children's Health (PUCRS), Master of Medical Sciences (PUCRS), Postgraduate degree in Emergency, Emergency and Trauma (SEG), Nurse Care of the Pediatric Intensive Care Unit of the Cardiology Institute in Porto Alegre-RS. Professor of the Course of Factum Practical Nursing, Professor of the Graduate Faseg, Porto Alegre, RS, Brazil

\section{Introduction}

The Leukemia is a malignant disease of the leukocytes, of unknown origin. Its main feature is the abnormal accumulation of young cells in the bone marrow, replace normal blood cells. The estimate for 2016 is 10,000 new cases of leukemia. Acute lymphocytic leukemia (ALL) occurs in lymphoid cells and worsens rapidly, the most common type in children. Diagnosis is made through changes in blood count and mielograma [1]. The Palliative care involves the care of the patient and their family, both considered care unit and that effective communication is paramount in the team's relationship with the patient and family, as well as teamwork is needed to cover all needs and dimensions of the person, respecting the autonomy of the patient, allowing him a peaceful death, natural, free of suffering and including the family during the process, especially in luto [2].

Goal

Describe the palliative care in the systematization of multidisciplinary care for hospitalized adolescents with acute lymphocytic leukemia.

\section{Method}

Descriptive study of a case study conducted in March and April 2017 with a teenager in the Inpatient Pediatric hospital private school. For the realization of multidisciplinary care to adolescents the following policy instruments were used: nursing research, North American Nursing Diagnosis Association (NANDA) [3] and Nursing Intervention Classification (NIC) [4].

\section{Results}

NCS, 10, white, male, student of elementary school, single parents, the second child. Admitted to the Pediatric Inpatient
Unit to undergo chemotherapy and subsequent surgical intervention cycle. The description of the findings on the chips corresponding to the history of nursing and Systematization of Nursing Assistance (SAE). The main nursing diagnoses assessed according to the taxonomy of the North American Nursing Diagnosis Association (NANDA) were swallowing and impaired physical mobility, pressure ulcer risk, exchange of gases harmed due to tumor growth, impaired verbal and interrupted family processes.

\section{Conclusion}

A videnciamos the fundamentality of multidisciplinary care for holistic care of patients with acute lymphocytic leukemia, contributing to recovery, maintenance and promotion of their health. In palliative approach, listening and paying attention becomes Thus, essential tools for the caregiver be learning to understand the patients with cancer and their families in their uniqueness. Therefore, it is important to enter the world of the patient, see things through their eyes and hear with their involvement experiences.

\section{References}

1. Schmiegelow K, Vestergaard T, Nielsen SM, Hjalgrím H (2008) Etiology of common childhood acute lymphoblastic leukemia: the adrenal hypothesis. Leukemia 22(12): 2137-2141.

2. Rodrigues GA (2004) Palliative care: concept analysis. Ribeirão Preto (SP) Ribeirao Preto College of Nursing.

3. Heather Herdman T, Shigemi Kamitsuru (2014) Nanda International, Inc. Nursing Diagnoses: Definitions \& Classification 2015-2017. $\left(10^{\text {th }}\right.$ edn), Wiley Blackwell, Oxford, UK.

4. Docheterman JM, Bulechek GM (2008) rating of nursing interventions (NIC). ( $4^{\text {th }}$ edn). Porto Alegre: Artmed, Brazil. 


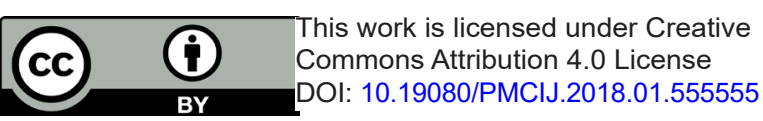

\section{Your next submission with Juniper Publishers will reach you the below assets}

- Quality Editorial service

- Swift Peer Review

- Reprints availability

- E-prints Service

- Manuscript Podcast for convenient understanding

- Global attainment for your research

- Manuscript accessibility in different formats ( Pdf, E-pub, Full Text, Audio)

- Unceasing customer service

Track the below URL for one-step submission https://juniperpublishers.com/online-submission.php 